\title{
Characteristic Features of the Zadruga (Extended Family) of the Croatian Subethnic Group of Bunjevci
}

\author{
Milana Černelić - Tihana Rubić \\ University of Zagreb, Faculty of Humanities and Social Sciences, Dept. of Ethnology and Cultural \\ Anthropology
}

\begin{abstract}
The aim of the article is to introduce certain characteristic features of life in extended families of Bunjevci in the different regions that they have inhabited since the $17^{\text {th }}$ century, with a focus on interrelations of the family members in everyday organization of life and work; the role of the master and the mistress - her duties in relation to other female family members; and (in)formal partition as well as some specific transitional forms of family life from the zadruga to nuclear families. The authors observe the zadruga phenomenon as a dynamic process, depending on the internal as well as the external socio-economic factors, and provide a comparative insight into the zadruga phenomenon in two branches of the same subethnic group, which largely reflects the historical and social circumstances in which such a family lifestyle existed and was transformed. The authors pay attention to the influence of common law, which had a great importance in preserving specific features of family life, despite the strong influence of historical, socio-political, ecological and economic factors on the Bunjevci family life structure in the final stage of the existence of the zadruga.
\end{abstract} Keywords: Primorje/Lika and Danube-area Bunjevci, family life, zadruga, common law

\section{INTRODUCTION}

\section{Basic interest and starting point}

This paper comparatively deals with particular aspects of life within the zadrugas (extended families) in different areas of Southeast Europe inhabited by Bunjevci, a group of ethnic Croats, originating from Dalmatia, south-eastern Bosnia and Herzegovina, separated in two recognizable branches. ${ }^{1}$

\footnotetext{
${ }^{1}$ Our research was carried out within two scientific projects approved and financed by the Croatian Ministry of Science, Education and Sports that specifically revolved around ethnocultural issues of this (sub)ethnic group in a wider spatial and temporal context. The first project was titled Identity and Ethnogenesis of the Littoral Bunjevci and was carried out between 2002 and 2006, while the other project, carried out between 2008 and 2013, was titled Identity and Ethnocultural Shaping of Bunjevci.
} 
The aim of the article is to introduce certain characteristic features of life in extended families of Bunjevci in the different regions that they have inhabited since the $17^{\text {th }}$ century, focusing on: interrelations of family members in the everyday organization of life and work; the role of the master and the mistress - her duties in relation to other female family members; and (in)formal partition as well as some specific transitional forms of family life from the zadruga to nuclear families. Our approach aims to observe the zadruga phenomenon as a dynamic process rather than a static one, depending on internal as well as external socio-economic factors. We also aim to provide a comparative insight into the zadruga phenomenon in two branches of the same subethnic group, which largely reflects the historical and social circumstances in which this type of family life existed and was transformed. Such an approach to the zadruga phenomenon was first taken in the 1970s by Eugine Hammel on a larger scale within the Southeast-European territories.

\section{Historical background: Who are the Bunjevci?}

Before discussing the theoretical background and approaches to the zadruga (extended family) phenomenon in Croatia and South-Eastern Europe, we shall provide a short historic survey of Bunjevci, the (sub)ethnic group, the identities of whom had first influenced migrations of uneven intensity, only to finally disunite the group.

In the $17^{\text {th }}$ century they migrated to the regions of Primorje (the Croatian Littoral), Lika and Gorski kotar, situated in western Croatia, and to the Danube area in the north (formerly part of the Austro-Hungarian Empire, today comprising the territories of Hungary and Serbia), thus forming three basic remote branches of the Bunjevci ethnic group, known as Dalmatia, Primorje/Lika and Danube-area Bunjevci (ČERNELIĆ 2006:13) (Figure 1). Migration, wars, rebellions and religious conversions are all dynamic factors that have formed the ethnic identity of Bunjevci. Apart from the three branches mentioned above, historians also mention the west-Bosnian (Ottoman) branch of Bunjevci, comprised of groups which settled in Dalmatia before the $17^{\text {th }}$ century (ŠARIĆ 2008:20). Waves of migration differed in terms of their time span and cause.

Primorje/Lika Bunjevci have inhabited the regions of Primorje (the Croatian Littoral), Lika and Krbava. Coming from North Dalmatia, they settled in the Primorje area in several stages. Following the defeat of Turks in Lika (1683-1687), a greater number of Primorje Bunjevci moved to Lika, where they encountered the other migration currents of Bunjevci (RoGić 1966:320).

Changing from the generic term (Vlach), the name Bunjevac itself must have been developed as an ethnonym on the Ottoman Frontier in the vicinity of Klis/Lika (around the Dinara and Velebit mountains) in the mid- $16^{\text {th }}$ century, and it can be grasped only within the context of the ethno-confessionalization of Vlach countries and religious division into confessionally opposed groups: Vlach-Orthodox (Rascian) and VlachCatholic (Bunjevac) (cf. ŠARIĆ 2008:25-26). Written record of the name Bunjevci first appeared in the second half of the $18^{\text {th }}$ century (ŠARIĆ 2008:28). Some historians have adopted the name Old-Croatian Vlachs for Catholic Morlachs in Dalmatia, who differ from the Balkan Vlachs in the interior with regards to their language and origin (MIRDITA 1995:78). These are actually groups of Bunjevci who have continually resided in the triborder region - so called Triplex Confinium - since 1520 (the latter being the meeting- 


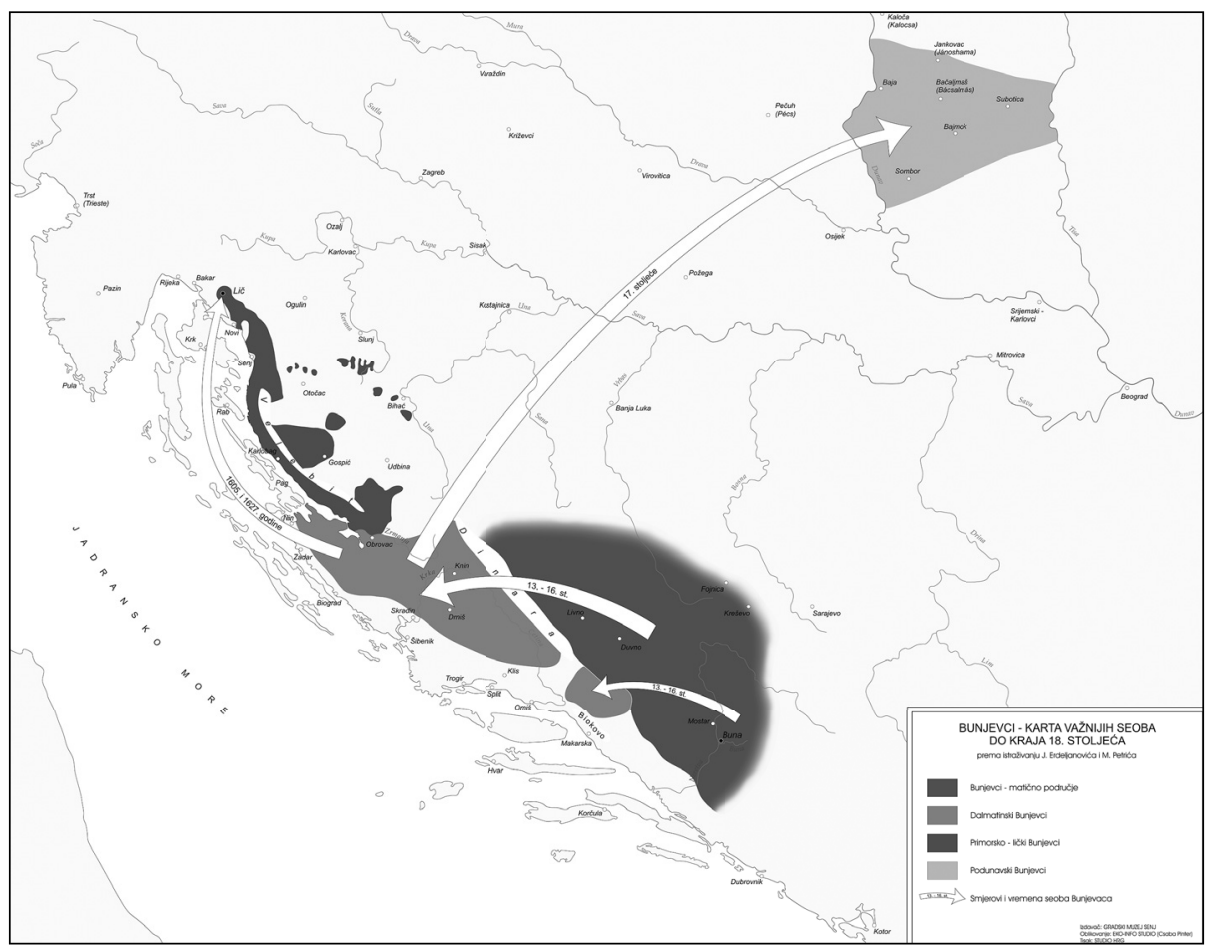

Figure 1. Map of the primary and secondary expansion and migration routes of Bunjevci from their original home area from the 13th to the 16th and in the 17th century. ${ }^{2}$ Original in City Muzeum of Senj. (Designed by Csaba Pinter - Eko-Info Studio, Sisak, Croatia)

point of three empires: Ottoman, Venetian and Habsburg), but the respective government apparatuses did not differentiate between them and the rest of the groups originating from the socio-historical stratum. For Ottoman rulers they were simply part of the Vlach social stratum, whereas the Venetian government knew them Catholic Morlachs (Morlachi del rito Latino) throughout the entire period of the early Modern Age, while the Habsburg Military-Border government also pointed out the Catholic traits of some of the Vlach settlers, but rarely used the name Bunjevci. ${ }^{3}$ Bunjevac settlers in Primorje, Lika and Krbava were also referred to as Catholic Vlachs (catholische Walachen), sometimes even as Catholic Rascians (Rasciani catholici). The ethnonym Bunjevac was not even used by the Hungarian county government in the Danube area during the $18^{\text {th }}$ century. Instead, the Bunjevac groups in the region were recognized as Dalmatians and

\footnotetext{
${ }^{2}$ The map is constructed for the purpose of the Ethnographic collection of the Littoral Bunjevci, the City Museum of Senj in 2006, based on research conducted by Jovan Erdeljanović in the 1930s (ERdeljanović 1930, Petrić 1966).

${ }^{3}$ Military Border constituted the borderland of the Habsburg Empire and later the Austro-Hungarian Monarchy, which acted to stop incursions from the Ottoman Empire. For more about Military Border see two monographs by Gunther E. Rothenberg (RoTHENBERG 1960; 1966) and also RoKsANDić 1988; PAVLIČEVIĆ 1989a; KASER 1997; 2003.
} 
Catholic Rascians, and sometimes, but more rarely - as Illyrians (Roman Catholics) (cf. ŠARIĆ 2008:27). According to scarce historical sources, the first migrations of Bunjevci to the Danube area already began in the $16^{\text {th }}$ century. However, several major waves of migration occurred during the $17^{\text {th }}$ century. ${ }^{4}$ This short historic preview of the (sub)ethnic group serves to highlight the territory of importance and the historical circumstances of migration among those recognized as ethnic Bunjevci.

Despite their great dispersion in space, Bunjevci communities share some common features: the ethnonym Bunjevac, the language (New Shtokavian dialect), collective memory (legends about the old homeland and the origin of the name), religion (Roman Catholicism), as well as certain common cultural features (ČERNELIĆ - RAJKOVIĆ IVETA 2010:291).

In our presentation, the focus is placed on the two Bunjevci branches, because integral research on the extended family life patterns has been undertaken within the territories inhabited precisely by these two branches of Bunjevci subethnic group. Initial research was conducted among Bunjevci in the area of Bukovica in northern Dalmatia (cf. BIRT - ČERNELIĆ 2014). ${ }^{5}$

\section{Theoretical background}

Numerous studies and discussions have been written on the zadruga by both Western and indigenous scholars. In this passage, the emphasis is placed on particular authors from both groups who studied extended families/co-operatives, some of whom are lesserknown to the wider scholarly audience but nevertheless important for our interpretation.

During the previous century, there was an emerging interest in family, kinship and social relations in the societies of South-Eastern Europe. Scholars from various disciplinary fields extensively discussed numerous aspects of family and kinship, scholarly interests being in large part directed towards kinship and family structures. "Classical" social research on family and kinship in the territory of South-Eastern Europe (in the Balkans) in the first half of the $20^{\text {th }}$ century contributed profoundly, for example, to knowledge about family and kinship structures in the past, historical family forms and demographic changes. The major segments of the research on family and kinship in South-Eastern Europe can be best summarized in several contributions that have earned international acclaim. Here we will mention only a few that are relevant to our focus of interest. Some of the contributors have been (co)authors of key works on family and social life as well as on South-Slavic social organizations in the Balkans (e.g. Hammel 1975; Filipović - Hammel 1982), which set out a wider comparative analysis (model) of households and families in the world.

\footnotetext{
${ }^{4}$ For more on the immigration of Bunjevci to the Danube region see: Bušrć 2005.

5 The third Dalmatia region Bunjevci branch is, in fact, no longer a subethnic group because they do not use the ethnonym Bunjevci in the same meaning as the other two branches. They are familiar with the term, but use it in a broader sense and only as a synonym for Catholics/Croats, not denoting any specific ethnic group. Thus, in this region the name Bunjevci directly relates to one's religious affiliation, i.e. Orthodox Serbs call their Catholic neighbours Bunjevci, often involving a derogatory connotation (cf. ČERNELIĆ 2007:583).
} 
Interest has continued throughout the last few decades, but has also garnered both the critique and revision of the earlier studies of/by international and indigenous scholars ${ }^{6}$. Moreover, the focus of interest has been slightly changed and transferred more towards comparative (temporal and regional) analysis researching past and/or present roles of a family and kin in changing societies (e.g. pre-industrial, industrial, post-socialist).

In the late $19^{\text {th }}$ century, extended families in South-Eastern Europe were interpreted by lawyers, followers of the so called Historical School of Law, whose founder was Friedrich Carl von Savigny (1779-1861). Their approach during field research was 'ethnographic' (through gathering data by means of questionnaires) and aimed towards understanding and appreciating common law, which they regarded crucial in the process of the legal standardization of rural families. (RIHTMAN-AUGUŠTIN 1984:18; KASER 1997:131; ČERNELIĆ 2009:304). This approach and methodology created the basis for works by Baltazar Bogišić on legal problems in extended and independent (nuclear) families, which, until the present, have remained an important starting point for ethnological studies of social life. This author claims that at the time of the disintegration of extended families "a whole range of different forms of families appear" - different in structure but the same in terms of relationship -, which indicates that socio-economic relations enable the renewal of rural extended family relations, although, by the end of the $19^{\text {th }}$ century, due to extended family division, stronger financial relations are forged among family members and personal property gains importance. A lack of understanding with regards to the system of living and relations within rural family forms and kinship relations is considered the main reason for the mistreatment of property and inheritance relations, which resulted in great problems, especially in cases involving the division of family property. Therein Bogišić became aware that it was due to misunderstanding of the rural culture and the subordination of individuals and their personal interests to the community, primarily to their families, but also to wider local community. (ČULINOvić-KonsTANTINOVIĆ 1993:31) In addition, Bogišić underlined the element of collective property as a key feature of an extended family as opposed to a nuclear family. Therefore, common economy and collective property are considered its distinctive features in comparison with a nuclear family. Bogišić pays no attention to the number of family members, focusing only on the following: the structure of family relations, the principles of labour division, the right of inheritance among the members and the collective property.

Collective property was seen as the fundamental feature distinguishing an extended family from a nuclear one, and the extended family was considered a legal and economic community of members by one other ethnologist as well - Milovan Gavazzi - who subscribed to Bogišić's earlier reasoning and also stressed the importance of the principle of indivisible collective property, common economy and the distribution of property among members (GAVAZZI 1978:82), placing it before the criterion of the number of members.

Gavazzi particularly considered economic and organisational aspects within the zadruga, elements of the traditional skills that were developing and taking place inside extended families, and he established a causal relationship between them and the existence of this type of family community. He claims, for example, how weaving

\footnotetext{
${ }^{6}$ For example, the current approaches and paradigms related to this topic have been extensively discussed in the special issue of Sociologija sela [Rural Sociology], one of the high-ranking Croatian scholarly journals in social sciences (the issue No. 43, 1974).
} 
skills were excellently "developed and preserved" precisely owing to the existence of the "socio-economic institution of South-Slavic extended family" (GAVAZZI 1978:62-63) Likewise, he attempted to interpret the origin of South-Slavic extended families and addressed the issue of the extended family in a wider European socio-economic context (GAVAZZI 1963; 1978:63). ${ }^{7}$ Apart from this, which is of special importance for our paper, Gavazzi pointed to the diversity of extended families, each one being a separate case, explaining that one could not find "two extended families with completely identical structures, the same property relations, the same living and working system, not even taking into account the difference in the number of members and their kinship relations, the quality and quantity of fixed and movable property and other characteristics which are, normally, distinct and unique, differing in each extended family" (GAVAZZI 1978:82; cf. ČERNELIĆ 1999:298; 2009:303; 2010:138-139).

Already in the 1970s, Eugene Hammel argued that extended family is a process (HAMMEL 1974; 1975; cf. TODOROVA 1986:7; KAZER [KASER] 2002:40), stressing that, in practice, social phenomena do not function as an invariable continuum (cf. Goody 1972:105). On this basis, critical thinking against earlier studies of the zadruga was formed within the Croatian ethnological circle as well, especially during the 1980s. Dunja Rihtman-Auguštin (1984) has given a most explicit critique of descriptions of the zadrugas in several Croatian ethnographic monographs from the first half of the $20^{\text {th }}$ century, in which the view of the zadruga as a static category was nurtured and perpetuated (RIHTMAN-AUGUŠTIN 1984). Zadruga was seen as an ideal type of an extended family wherein there were, allegedly, no greater structural changes. Some have critically noted similar stereotypes perpetuated by Croatian historians during the $20^{\text {th }}$ century (LEČEK 2003:312). This idealization of extended family life has been supported by an idea of harmonious functioning within large family units and households in the past, and the lack of unity as the predominant value system was seen as the cause of the breakdown of the zadrugas.

However, there are two levels permanently present in the life of the researched families: one of them is value-oriented, imaginary (as it should be), and the other one is real (the way it is in a concrete case) (cf. RIHTMAN-AugušTin 1984:13-15) - which is similar to Peter Laslett's differentiation between "familial ideology" and "familial experience". (cf. LASLETT 1972:63-85). Within Croatian ethnology, Jasna Čapo Žmegač was also an advocate of the process continuity, relying on the theoretical propositions and research by Hammel. She underlined that "(n)uclear (...) families and households in the common property-law system also belong to the zadruga type, and potentially, through families' branching, a household consisting of a husband, wife and children, in which the adult son and his spouse

\footnotetext{
${ }^{7}$ Precisely on the initiative of Milovan Gavazzi, in the 1960s an idea of describing life in individual extended families gained sway, which resulted in research within his project Rural extended families in the $19^{\text {th }}$ and the $20^{\text {th }}$ century, and the body of materials on extended families can be found in the archives of the Department of Ethnology and Cultural Anthropology at the Faculty of Humanities and Social Sciences in Zagreb. The project came out with two volumes of collected papers entitled Seljačke obiteljske zadruge I [Rural Extended Families] (Gavazzi 1960) and Seljačke obiteljske zadruge II (ОВАD 1992). In respect of their structure and the focus of interest, descriptions of individual extended families are rather uniform due to the tendency towards further comparative analyses of the time. They contain data on family members (family tree), on the zadruga household, on property, on economy and work, management, the organisation of everyday life, the regulation of family members' duties and rights, and on the partition of the zadruga.
} 
continue living with their parents instead of establishing their own independent household, also develops into an extended family, that is to say a household comprised of several nuclear families, but with no changes to the basic ownership and inheritance structure. In this view, nuclear and expanded families are not two types of families but rather one of the same type in different points of its existence" (ČAPO ŽMEGAČ 1998:256; cf. KASER 1997:132). Many studies by the aforementioned Croatian ethnologists (ČERnELIĆ 1999; 2009; ČAPO ŽMEGAČ 1998) and historians (LEČEK 2003) were done exactly in accordance with this critical thinking, having taken an approach that underlines the constant variability of the extended family structure (the make-up and number of members), as well as social and economic circumstances affecting the structure of families and households.

Thus, extended types of families and households, termed the zadrugas, should be seen as variable communities rather than homogenous ones, to a large degree dependent on wider social, local as well as familial circumstances, which ultimately make zadruga more a social phenomenon than an institution (TODOROVA 1986:7). In the mid-seventies of the $20^{\text {th }}$ century, the interest of French zadruga expert Emile Sicard was directed towards the economic importance of Croatian extended families through history. He pointed out the multileveled relations among different authorities within an extended family, and identified the extended family as a primarily household and economic community (shared work and life) and only then a familial community (due to existence of some non-kin relations as well). Sicard's text is of an exceptional importance in terms of creating and explicating the multileveled model of various relations among different authorities within an extended family (SICARD 1974; cf. FirST-Dilić 1974; RinTMAN-AuguŠTin 2004:24), and in terms of highlighting the economic practices and relations within zadrugas.

Communities based on familial or kinship work and common economy had a shared interest in the survival of both individual economy and inheritance in the best interest of the particular household and familial community. Each of these communities were organized in accordance with the current circumstances and interests (in terms of the maximum benefit for the family and household), rather than according to a certain (general, uniform) pattern which would make life and family circumstances within all the extended families (more or less) the same. Even today, within a single local community one cannot speak of identical families and households. Thus, when studying families and households we should take into account the constant dynamics of the process and variability of structure within a single family (ČAPO ŽMEGAČ 1996:185) and many informal practices within families, which do not always strictly adhere to the laws.

Furthermore, when using the concept "cyclical micro-variations" of household, Eugine Hammel has taken into consideration different levels of dynamics (not statics) in the structure of households, even those that are seasonal: "households may have a developmental cycle and that there may also be seasonal variations in their structure"(HAMmel 1972:337; cf. Todorova 1986:7-8). The (non-)survival of extended families is influenced by individual and family reasons, practical interests and subjective (cf. SteIn ERLich 1964:338-340) reasons, apart from social circumstances, that, depending on the period, may have positive or negative effects on the preservation or partition of a particular extended family - such was an example of the world agrarian crisis in the second half of the $19^{\text {th }}$ century (cf. BIĆANIĆ 1937; cf. STEIN ERLICH 1964:334-335).

In one theoretical text on the study of family and kinship, French anthropologist Martine Segalen commented on the trap of simplifying general assumptions about 
families in the past, specifying the very importance of the context and circumstances which had different effects on family and household communities, by stating the following: "depending on whether in the focus of research is the family institution in the context of powerful industrialization (...) or protoindustrialization, one obtains a significantly different picture of family relations" (SEGALEN 1997:35). Similarly, M. Todorova had earlier indicated the importance of a holistic approach to zadruga as "a complex structure and process alike, possessing a number of diverse valencies, such as kinship, property relations, residence, working arrangements, and so forth. Taken in isolation and elaborated as the sole basis of approach, each of these valencies would produce a one-sided definition and description, which would be valid for as many cases as there would be exceptions" (ToDorova 1986:8). We find the holistic approach to zadruga as a complex structure and process rather important and try to apply it throughout our comparative analysis of particular characteristic features of the zadrugas of the Bunjevci.

Let us now refer to the typology of households from 1972 - one of the most cited and referred to within a large corpus of works in the field of familial and demographic history. It was the one by Peter Laslett from the extensive volume he edited with Richard Wall. In the introductory contribution to this volume, Laslett did not explicitly mention extended families and/or zadrugas (unlike Hammel). One can assume that he considered them in the classification and typology, at least because Laslett did conduct research in the territory which is familiar with this institution (Serbia, Belgrade and the neighbouring region) (see: LASLETT - CLARKE 1972:375-400). Within Laslett's typology, the type of "multiple family household" (1974:36-37), in its extended variant, could correspond to the one of an extended family. Nevertheless, Laslett's typology is oriented towards kinship structure within a household, according to which there are both simple and extended forms of family households (simple family household, extended family household and multiple family household) (ibid., 28-29). However, it does not include the structure of ownership, economic and property relations - and this we find the key differential feature of an extended family (zadruga) as opposed to other forms of families and households. Notwithstanding its indisputable importance for the history of family in the European context, Laslett's typology is not sufficiently precise for the purpose of this paper. ${ }^{8}$

\footnotetext{
${ }^{8}$ Let us briefly mention two earlier critics of Peter Laslett's typology (relevant to our scope of interest). The first one is a critique by Bulgarian ethnologist Maria Todorova, who notices that it is mostly "impossible to identify with one or more proposed family types in Laslett's classification"(ToDOROVA 1986:16) and that Laslett's typology is not "perfectly applicable to the Balkan region"(ibid., 18). She also indicated that the size of household is not sufficient data when it comes to zadrugas. Therefore, she proposed shifting the focus on other aspects important for the research, such as "age at marriage, age of birth of first and last child, frequency of remarriage, and many others (ToDOROva 1986:19). The second one is the critique of a particular simplified classification of European family models into the West and the East (John Hajnal's division between the European and non-European civilizations of Eastern Europe, see HajnaL 1965). Croatian etnologist Jasna Čapo Žmegač critically addressed "the geographic distribution of the different family forms" (TODOROva 1986:16) in Laslett's family typology, stating that although Laslett stresses that geographic implications are complex and confusing, and that the whole issue was not researched thoroughly enough, he implies a certain geographic distribution of European family (LASLETT 1977:91, 96, 98; according to ČAPO ŽMEGAČ 1996:181-183).
} 


\section{The zadruga: common law, legal framework and socio-economic context}

In a short review of Bogišić's approach to the study of family we have touched on the importance of common law for the organization of the extended family. Certain lawyers and ethnologists view common law as "all written and unwritten norms of social behavior, economic, social and family relations (including moral values), which existed and were developed in traditional rural environments, regulating the internal life of these social communities, notwithstanding the existing legal norms of the country". (ČULINovićKonstantinović 1984:52) One should bear in mind that "tradition ensures continuity of cultural heritage in the course of history. Cultural heritage, yet, exists independently of the system of government, but relatively dependently on social system (feudalism, capitalism, socialism), wherein, with certain delay, it shapes more or less new models of relations and behavior" (ČUlinOvić-KonstantinOvić 1984:53-54). Alongside the common-law regulation of traditional heritage there are state laws, which were also based, in their origin, on common law and had validated certain common-law norms during a longer period of time in the course of history. In this way, by introducing state laws, legal dualism is fostered. Up to the $19^{\text {th }}$ century, common-law norms affected the process of legislation adjusting the law to national tradition (ČuLINOvić-KonstantinOvić 1984:55-56). Until and after 1881, Croatian historian Dragutin Pavličević greatly contributed to the research of extended family legislation within the Military Border with his two books on Croatian extended families, in which he offers detailed insight into legislation of extended families in the $19^{\text {th }}$ and the $20^{\text {th }}$ century. The first law on extended families ever was passed within the Basic Law of the Border in 1807. This law was based on the common law which was in force in Croatian territory within the Military Border at the time, and it was the first attempt at standardizing extended family life in general (PAVLIČEvić 1989:274). However, after demilitarization of the Military Border, in attempts to legally regulate the extended family issue in civil Croatia, there was a discrepancy between the Civil Law and the extended family (common) law - in all laws passed from 1870 to 1880 , especially in respect of property, inheritance and so called women's rights. This resulted in the passage of numerous acts on extended families, which in turn brought about many lawsuits, legal actions and secret partitions, etc. (PAVLIČEVIĆ 1989:334-335). Attempts at the legal regulation of extended family relations continued up to 1918. Towards the end of the $19^{\text {th }}$ century, extended families were increasingly contrasted to the general situation in the society. The general tendency towards individual production was becoming more and more evident, which is best illustrated by the statistics on the internal partitions of extended families. Basically, all laws on extended families strove towards the preservation of this type of family system. (cf. Čulinović 1953:166-168.) Ethnologist Gavazzi also pointed to the legal aspect of the continual existence of extended families, stating that "the tradition of living within the extended family, together with shared property in South-Slavic rural parts, persistently survived this long owing to the system of taxation in according to which taxes were collected by the 'chimney smoke', that is, depending on the number of hearths. Thus, normally, in rural families that had parents with alreadygrown sons who had already married, their grandchildren, and even great-grandchildren, stayed together as a single community, an extended family - all of them around a single ancestral hearth, and these kinds of systems had existed from the early Middle Ages up to the end of Turkish rule in the Balkans" (GavazZI 1959:11). 
However, even though this kind of artificial support facilitated the preservation of extended families, the beginning of the end of the latter should be traced to specific circumstances of the Military Border regime. Militarization of the Military Border in the late $18^{\text {th }}$ century and the early $19^{\text {th }}$ century disrupted the traditional division of labor in patriarchal society; women increasingly started taking up men's jobs, which led to overburdening of the female labor force. A series of years of famine also aggravated the disruption of agricultural production, and in these circumstances mutual assistance within an extended family lessened, all of which paved the way for the final breakdown of extended families. According to these indicators, militarization of the Military Border is one of the causes behind the process of extended family disintegration (cf. RoKSANDIĆ 1988:100-102; KASER 1997:164-167). After the mid-19 ${ }^{\text {th }}$ century, the tendency towards disintegration of the extended family system grew further. The causes of this were seen in external factors (socio-economic circumstances, unsuitable legal regulations) as well as in internal ones. In addition, Karl Kaser, for example, highlighted the difference between socio-ethnic groups in relation to zadrugas in one period of Military Border, its constitutions and dissolution: Vlachs and Bunjevci preferred to live in zadrugas, as opposed to Croats in other regions of the Military Border area (KASER 1997:196).

Economist and rural sociologist Rudolf Bićanić stated the following: "The disintegration of the extended family is, in a way, 'a long-lasting process' which cannot be analyzed on the basis of a single extended family or a single law, but rather within a general socio-economic context. For this very reason, the causes of the partition of the extended family are demographic, technical, economic, political and cultural, although, in the order of importance, economic and demographic factors come first" (BIĆANIĆ 1936:25-28). Furthermore, he reasoned that agrarian and general crisis had led to the intensifying of the process of partition. He provided concrete economic evidence for the crisis and its impact on the disintegration of extended families: higher taxes, retailers entering the rural market with cheap merchandise, the introduction of railways, which accelerated the transportation of goods and utilization of land, industries which provided earning opportunities outside the extended family, the opening of the capitalist market and the lowering of wheat prices. All of this brought about "a demand for change in the methods and intensity of land cultivation, which the old self-sufficient extended family, with its internal structure and organization, could not meet. Disputes and discord, an ambition for separation and reliance on one's own individual property (osebunjak) that was supposed to provide additional means of livelihood, appeared within the extended family. Individuals were trying to improve their position by quitting the extended family and adopting the new economic method. Thus, one can conclude that specifically economic reasons in production and consumption were the main triggers of partition and the disintegration of the extended family at the time of crisis in the 70s and $80 \mathrm{~s}$ of the $19^{\text {th }}$ century." Bićanić also identified the causative connection between the disintegration of extended families and the frequent search for additional earnings - both inside the country and by emigrating abroad, primarily overseas (BIĆANIĆ 1936: 25-28). ${ }^{9}$ Croatian ethnologist Jadranka Grbic links the causes of emigration with the context of extended families' disintegration following the cancelling of the Military Border:

${ }_{9}^{9}$ The most intense emigration from Europe to America occured between 1880s and 1920s. (Cf. ČIzMIĆ 1982.) 
"after shared households had disappeared, many small families struggled to make a living on the land that was left to them after the partition. Keeping in mind the lack of investment in development and therefore the slow pace of industrialization throughout the entire territory of Croatia and, in turn, an extremely low employment rate, high taxes and peasant debt - it was natural that many saw their salvation in migration". (GRBIĆ 2006:14)

\section{THE ZADRUGA FAMILY LIFE OF THE BUNJEVCI}

In the context of the described socio-economic circumstances, wherein the extended family type was disintegrating - or continued existing, which, with the lack of thorough insight into practices of zadruga family life i.e. the prominent use of descriptive methods is rather unusual (KASER 1997:133; TODOROva 1986:17), we will now attempt to qualitatively depict particular segments of extended family life within branches of Bunjevci. The economic lives of Bunjevci peoples in both the Primorje/Lika and the Danube area were quite different due to their socio-economic framework. (Cf. ČERNELIĆ 2005:35-40) Despite the differences, certain forms of the extended family system could be found within both branches of Bunjevci.

Therefore, the comparative approach plays a prominent role in our analysis of the family life of the two Bunjevci branches. The approach is not simple to implement, as ethnographic differences within each of the branches are evident. We will thus illustrate some individual cases to indicate and discuss the peculiarities deriving from the internal and, up to a certain degree, the informal organization of life within a particular family in each of these two Bunjevci branches. On the basis of ethnographic insight into this phenomenon, we will point to tendencies in retaining certain features of co-resistance after the (in)formal partition of the zadruga. As revealed by the results of research focusing on their cultural heritage, these tendencies and features can be recognized in both branches. Our aim is to present the Bunjevci zadrugas as a process, based on the mentioned theoretical approach inaugurated by Hammel. Our approach is based on ethnographic data concerning individual families. Milovan Gavazzi's idea was also to focus on the research of individual zadruga families, which is applicable in our research as well. Our aim is to reach conclusions by comparing particular features of individual zadruga families in their final phase of existence. Such an approach should result in cognition about the possible existence of many individual variations, which in some aspects have certain common characteristics. Based on these perceptions, our starting point is that the common law was a highly relevant factor in the regulation of zadruga family life, more or less adjusting to legislative rules in a certain period of time and space.

\section{The Primorje/Lika Bunjevci branch}

Socio-economic factors, primarily economy-driven emigration, played an important part in the disintegration of extended families in Lika and Primorje as well as in creating specific modes of managing and establishing thus conditioned property relations in particular un-partitioned extended families who managed to survive the general economic crisis. 
Therefore, it is necessary to consider that "a family is a social group with an extremely important economic function in rural life" (RIHTMAN-AUGUŠTIN 1984:17). Ethnological research of extended families in this region shows that in such circumstances members of particular extended families tended to address the issue of organization or partition of their familial communities on their own. As a consequence, familial communities either ceased to function internally, or continued to function as an extended family according to an agreement among the members.

\section{The role of the master and the mistress}

The master and the mistress have important roles in organization of everyday family life and labor. This is more or less based on age and gender structure, which means that the oldest male member of the family is regularly the master of the family. If he is not alive, the second oldest member takes over the duty. The role of the mistress was important, especially with respect to the female members of the family, but in certain situations her role was even more significant. She conducted and coordinated the women's work and their duties, she herself undertaking some of the basic duties in the household. Such a familial order and the established rights and duties of all the members of the extended family were mostly in line with the acts of the Basic Law of the Border after 1807 with integral common-law norms according to which the organization of the zadruga life is basically structured (PAVLIČEVIĆ 1989:274-277). These are the general standards, which may be considered a model of the family administration, but sometimes, in practice, these rules are somewhat different. Older literature makes no mention of any external influences that might disrupt the well-established order of the extended family, while the only mentioned potential internal disturbance of relationships is in terms of determined sanctions against its members, including the master, if he does not perform his duties according to the rules and if he disrupts the extended family's order. However, no concrete examples of their actual application are provided (ČERNELIĆ 2009:313). Research done in the 1980s and in the last few years offers more detailed records of some individual families in the temporal and social context, indicating that the standard order was readjusted to the particular situation that caused some specific modes of conducting the family and common economy. The general principles of the zadruga regulations were respected, which was in fact the postulate of its existence and survival, but it was necessary to regulate interrelationships and the organization of life and homestead, adjusting these to particular family circumstances.

Specific circumstances of management, labor distribution and (in)formal partition in the final stage of zadruga existence

Data from earlier literary sources quite often offer a simplified picture of a stable arrangement and order, ideal administration and relationships among members of the zadruga families, without providing any information about its functioning when, for example, all male members of the family are absent and work outside the family. In these cases, the regular distribution of labor between male and female members is disturbed. This was the case in the Military Border, when male labor was primarily taken on by women. The evidence of disturbance in the clear distribution between male and female work can, nevertheless, be found in some descriptions of the Military Border circumstances at the end of the $18^{\text {th }}$ century: According to Hacquet's claims, at the 
end of the $18^{\text {th }}$ century "poor" Lika women did "all" agricultural work. He especially emphasizes, obviously due to the degree of its difficulty, ploughing with the use of a "plough with no wheels"... "The hardest and the simplest" duties in the extended family homestead are done by the youngest woman (RoKSANDIĆ 1988:25).

The results of the research on the zadruga, carried out in some regions inhabited by the Primorje/Lika Bunjevci in the 1980s and in the first decade if the $21^{\text {st }}$ century will best illustrate the attributes of extended families in the final stage of their existence in the first half of the $20^{\text {th }}$ century. Under normal conditions, the division of labor was based on the standard zadruga rules of distribution into male and female work, adapted to specific circumstances within the family, depending on the number of its male and female members. The mistress was responsible for cooking and doing most housework, while other women helped her upon agreement. If there were fewer women in the household, the mistress would take on the rest of the housework which was usually outside her domain. Methods of labor distribution differed among various extended families. The lack of a male labor force largely determined the organization of an extended family and the distribution of work in the final stage of zadruga existence. Male members of the family were often absent from the household in order to earn money for the family, especially when the father, as the master of the family, was still alive; in the period of transatlantic emigrations, most intensively from the 1880s to the 1920s, in different regions of the Austro-Hungarian Monarchy, Kingdom of Serbia or the Serbo-CroatianSlovenian Kingdom (named Yugoslavia from 1929) during the period of the state's existence (first half of the $20^{\text {th }}$ century), as well as in the Socialist Federative Republic of Yugoslavia in the 60s during the wave of labor emigration to West Germany from those rare zadrugas that still survived by the second half of the $20^{\text {th }}$ century (Cf. ČERNELIĆ 2006:41-43; 2009:307, 309-312, 315). In most zadrugas, one of the brothers usually stayed in the household after the father died, taking over the management of the family. In many cases, the mistress took over the management, especially during the period when men were absent. Men most often worked as bricklayers (which was a common occupation at that time), but they also did other jobs, such as woodcutting work, road construction, building tunnels, and so on. In these circumstances, the mistress organized the work of both the absent male and female members of the family. She herself did most of the household work: cooking, making bread, collecting eggs (planinka - mountain woman), and taking care of children. If she could not handle all the jobs on her own, her daughter or/and the youngest daughter-in-law helped her. Other women worked in the field because men were also absent during the field work season. In the Primorje/ Lika Bunjevci branch, the mistress most often took over the managing role after the death of the master, but that duty was often formally assigned to the oldest son, who, if not absent, performed all the work outside the household. In addition to the above, male members of the family in the region of Primorje and Lika frequently migrated to countries overseas from the end of the $19^{\text {th }}$ to the beginning of the $20^{\text {th }}$ century. This was the most intensive period of migration and the most common reason for the partition of extended families, but this cannot be taken as a general fact. Quite often families did not separate, but simply reorganized managing strategies and homestead activities, adapting them to the specific situation in each family. Recent research in the region of Lika in May 2010 (the local community of Lovinac) indicates that the zadruga members who migrated to the United States, Canada or to some South American states were obliged 
to support the family financially. They were still considered members of the zadruga, keeping the right to legal inheritance in the event of its partition. In contrast to the usual idea that economic migration caused the disintegration of the zadruga, the informants claimed that emigration did not contribute to it - on the contrary, the emigrants in fact helped the zadruga to become more economically stable. For example, in one zadruga from Brušane, a village near Gospić in Lika, after the death of the last master in 1938, his wife conducted the family, even though the oldest son had formally taken over family management. He performed all the work outside the zadruga household instead of his mother. At that time, he was the only male member of the household since his younger brother was a transatlantic emigrant. The zadruga did not disintegrate at the moment of the master's death, the result of a conscious decision by its members, even though they had earlier considered the possibility of partition. Since the son who worked and lived in the zadruga died earlier than his mother (the mistress), the other son came back from abroad in order to help and take care of his mother. In this zadruga, as well as in some others in the region of Lika, the disintegration occurred as a natural process caused by specific family circumstances and without formal partition being implemented (like in other settlements in Lika, such as Lovinac and Trnovac) (cf. ČERNELIĆ 2009:314). Economic migration in different periods of time was certainly an important factor in the partition of the extended family; at the same time, it produced some specific modes of family life within the zadrugas that survived the economic crises. After they had been (in)formally divided, certain attributes of the extended family structure were retained as well, having been adjusted to the specific circumstances of a particular family.

These changes contributed to the mistress becoming the central authority of the zadruga, and the extended family structure, in appropriate forms, survived up to approximately the mid- $20^{\text {th }}$ century, and in certain cases even longer. For example, in two generations of the one family in the village of Smiljansko polje near Gospić, women took over the administration of the zadruga because men were absent (cf. ČERNELIĆ 1999:300, 308; 2009:311, 315). After their father's death, both brothers emigrated to Canada and Argentina, leaving the women alone with children. The husband of the mistress left for Argentina soon after they married. In the meantime, she gave birth to their son and on her husband's first visit home she got pregnant again. Afterwards, he never returned from emigration. The two women did not get on well and disagreed, so the old zadruga was divided in 1931 and one woman became the mistress of the newly established zadruga with her sons. When her sons married, her older son took over the management of activities outside the zadruga, but the woman remained the mistress, arranging all important matters with regards to family life and economy. This zadruga survived all the way up to the 1990s. Her sons left in the late 1960s for temporary employment in West Germany, which was common in former Yugoslavia at that time, thus contributing to the better economic prosperity of the family. Before they left, and after they came back, they had worked in the field together with the women as well as attending to other additional work outside the zadruga. The mistress's duty was cooking and taking the food to the field during seasonal fieldwork in addition to doing other housework, except laundry. At the time of the research (1981), the mistress's only duty was to deliver and sell milk, but she was not obliged to do anything else unless she wanted to. Her daughters-in-law took over the cooking and other activities in the household, deciding how to share duties together. The distribution of work was no longer as strict as before (cf. ČERNELIĆ 2009:311, 315.). 
The narration of an informant from the nearby village of Trnovac near Gospić, provides an interesting perspective on the zadruga in its final stage of existence: one male member of the zadruga usually worked in the field, others would work in the woods, factories or in the United States, providing the family with a certain portion of their earnings, which was regulated according to their income levels. Each member of the zadruga could only have claimed his part of the inheritance if he had contributed to the zadruga for thirty years. If he had ceased to provide financial support, he lost the right to his part of the family heritage (ČERNELIĆ 2009:309).

\section{Examples of transitional forms, from extended to nuclear family (gradual partition)}

In some extended families of the Primorje Bunjevci in the region of Krivi Put, members of the divided zadrugas lived for two or three years in the same place, even after the formal partition (achieved via agreement without legal procedure), making common use of the former zadruga tools where appropriate, even working interchangeably on plots in the field that were not yet divided. Some of them remained living in the same place afterwards as they could not afford to establish new households on their own, forced to share the former common house due to economic reasons, but cooking and working separately, even though they would also rather live separately. This transitional form of living might be defined as a temporary co-residence of two or more nuclear families (ČERNELIĆ 2006:52). Even in the examples of extended families in Lika mentioned above, there was no formal partition in their final stage. Instead, they survived due to their tendency of preserving certain aspects of zadruga life for the purpose of easier management in harsh economic conditions, which triggered overseas emigrations and led to the later disintegration of the family as part of a natural process and in accordance with specific family circumstances. There is a similar type of familial co-existence in the same location, the difference being that there are neither zadrugas nor any transitional forms between an extended and a nuclear family. In this case, two brothers live in their parents' house due to financial constraints, each with his own family, but according to the principle of two individual households, without shared work and economy, both seeking to set up (autonomous) homesteads of their own as soon as an opportunity arises for either of them (cf. RUBIĆ - BIRT 2009:50-52). This type of household may correspond to Laslett's term "houseful", which "may contain several households" (Goody 1972:105). According to Laslett's definition, common location is the most important criterion when discussing "domestic group" (LASLETT 1972:36). In those terms, the co-residence of two or more nuclear kin families may represent a "domestic group." The aforementioned examples of family structures occurring during the transition from extended family to a nuclear one make for the same or a similar type of a familial community, but formed under different circumstances.

\section{The Danube area Bunjevci branch}

Although external factors which influenced the existence of particular zadrugas within the Primorje/Lika Bunjevci differ as compared to the Danube area Bunjevci, the latter branch of Bunjevci also tended to preserve zadrugas in conditions when this family system was disintegrating, both in their own environment and in a wider social context. 
Proving specific examples, we will attempt to indicate different modes of preserving the zadruga system in its final stage of existence in the Danube area as well.

\section{The role of the master and the mistress}

The rules concerning the duties of the master and the mistress are more or less the same as those of the Primorje/Lika Bunjevci branch. According to a general rule, the oldest son became his father's successor. Nevertheless, in some cases, his wife, the mistress, took over the managing role in the zadruga. Most often, however, it was the oldest son - or the most capable one - who took over duties which the master had performed and in this way became the mistress' deputy (ČERNELIĆ 2006:143). In some cases, when the master was not alive any more, the brothers mastered together by agreement (ČERNELIĆ 2011:199).

\section{Specific forms of management and division of labour in the final stage of zadruga existence}

The mode of conducting the zadruga among the Danube area Bunjevci ethnic group is specific in some aspects. Sometimes the master and the mistress lived in the city - apart from the other members of the family. The sons were obliged to give parents a certain portion of the common income (komencija). The master supervised the work of the family members and he disposed of the property, but his oldest son governed the current work, and, in agreement with his brothers, decided what work was to be done. This way of zadruga administration is special due to the separate living arrangements described above and entails a kind of parallel seniority. As a rule, sons worked in the field and the father monitored their work and disposed of money and property (ČERNELIĆ 2006:146; 2010:112, 125-126). For instance, in one extended family near the town of Sombor, despite his father's authority and management, the oldest son took care of some of his tasks, such as trade and dealings with authorities, which meant that even after his father's death he kept performing the same duties while, in a formal sense, it was his mother who actually took the control of the zadruga. In some extended families (one in Tavankut, near Subotica), members did not live under one roof because of their sheer numbers; they moved to different farms ( salaš), but retained the practice of common economy and ownership (ČERNELIĆ 2006:146).

Although the distribution of labor, especially the kind performed by women within the Primorje/Lika Bunjevci zadruga, was not given detailed consideration in this paper, on the basis of the insight into the final stage of its existence, one can note certain similarities. As opposed to the Primorje/Lika Bunjevci branch, men of the Danube branch most often worked within the zadruga, but similarly, women took over their duties if some of the men were absent for any reason. Areas inhabited by the Danube region Bunjevci are rich in fertile soil, and there was therefore no need to earn a living outside the extended family circle. Nonetheless, in some cases certain male family members did other jobs, earning money outside the zadruga and in this way contributing to the community. Regional modalities of female labor distribution among the Danube area Bunjevci in southern Hungary varied; the duty of the mistress is to cook and do most of the work in the household; other women help her upon agreement; the mistress cooks and makes the bread and other women assist her when necessary (one zadruga in Kaćmar). In one zadruga, in the village of Čavolj, the mistress was cooking and one of her daughters-in-law was processing the milk products while the other one had no 
specific duties except working in the field instead of her husband, who was working outside the zadruga as a craftsman. A specific modality is confirmed among the regional group of the Danube area Bunjevci near Budapest in Hungary: the mistress cooked, and her daughters-in-law consecutively changed subsidiary tasks. In most zadrugas in the region of Bačka in Serbia as well as in some in southern Hungary, women alternated every week in performing household work, primarily in cooking, but their other duties were variously arranged from zadruga to zadruga (the so called reduša) (ČERNELIĆ 2006:144-145). In some extended families (for example on a farm in Đurđin) one woman was especially chosen to take care of poultry - named stanarica - the (in) dweller; in some other zadrugas, the name denoted a woman whose duty was to process milk products (ČERNELIĆ 2006; 2010:126-127). Even within the Danube area Bunjevci branch, these variations in the distribution of labour among women were adjusted to the living circumstances of the zadruga in its final stage, when life and work organization took on specific forms adapted to the relations and circumstances of the given family.

\section{Examples of co-existence among family members after internal zadruga partition}

Life in the zadruga in its final stage among the regional Danube area Bunjevci grouping in southern Hungary had specific aspects. All family members were living together for a certain period of time, but they worked separately; in some families they cooked together awhile, and sometimes they worked separately, but organization was the same as when they functioned as a zadruga; if the father was alive, the sons worked for him to earn money for food and clothing. In some cases, the master provided them with food for a year in order to enable them to gradually prepare themselves for independent living, and even when they were completely separated, they still continued to help each other (ČERNELIĆ 2006:146-147). In some zadrugas of the Danube area Bunjevci in Serbia (Subotica), the master tried to prevent the partition by persuading his sons to stay together. Even if the extended family had been divided internally (not legally), the land was still common property, even though members of the family used it separately (according to internal agreement) (ČERNELIĆ 2006:148-149). In case of partition, sons were obliged to provide common income (komencija) in order to financially support their parents, or parents stayed with the family of one of their sons, who took care of them and would, as a rule, consequently inherit a larger portion of the family property. A tendency towards internal land distribution among the members of the extended family was prominent even before the actual partition of Bunjevci zadrugas in southern Hungary. These kinds of extended families were gradually partitioned and one can say they died out naturally, as in the example of one zadruga in Gara (southern Hungary), wherein, after their father's death, two out of four brothers stayed with their mother, each of them in his own part of the house, and each family cultivated their parts of the land separately. They cooked together, and after the mother's death, they retained their living arrangements, but started cooking separately (ČERNELIĆ 2006:149, 146). Further examples among Bunjevci in southern Hungary will illustrate additional modes of co-existence in the final stage of zadruga life or after the internal partition. In one extended family in Aljmaš, two brothers had their own farm buildings and worked separately, but the organization of labor was very similar to the one from the times of common economy. Each brother provided an even portion of the common income to the parents and their unmarried sister. They cooked together and equally invested in the kitchen. After each brother started taking care of his own family, 
they became somewhat like tenant farmers (arendaši) on their own parents' property. One extended family in Čavolj had a similar situation. Two brothers worked together for their father for food and clothing. Even before partition, the father had decided that they were going to be dependent on him (live by his bread) for a year in order to prepare themselves for standalone living. During this period each of the sons, with his family, had a separate room and his own farm buildings. They worked according to the father's demands, one in the field and the other as a bricklayer outside the household. The latter's wife worked in the field instead of him, and the earnings from his craft went to their nuclear family. In 1927, when the brothers launched their own independent households (ošli obaška na $k r u v$, meaning that they were not using the same bread any more), the son who worked in the field continued doing the same for his father for a half (na polak), and thus the yield was divided into equal portions. The other brother, apart from doing the bricklayer's job, took some land on lease, which was cultivated by his brother, for which he compensated by hilling up or offering his bricklaying services to his brother as needed. The land was still cultivated through the use of the old common zadruga tools. This kind of relationship between brothers was kept after the father's death. There are other similar examples of specific family relations adjusted to a particular situation, which indicate certain modes of zadruga management and the relations among the members of the family who were living together for a period of time after the internal partition, taking care of parents, helping each other and working together, although property relations changed after particular nuclear families within the former extended families had become independent (ČERNELIĆ 2006:146-147). There are also examples in the extended families within Bunjevci branch in Bačka, in Serbia, near Subotica (one zadruga from Žednik), wherein land was already divided some time before the formal breakdown of the zadruga following the departure of one son from the extended family. The remaining members of the extended family lived and worked together for the next ten years (ČERNELIĆ 2006:148).

These cases reflect specific modes of co-residence in two nuclear families, representing a specific type of family with its subtypes as transitional forms in the process of transforming from an extended family to a nuclear one, in circumstances of gradual zadruga disintegration.

\section{FINAL REMARKS}

Our research has shown that the general principles of family life and structure were regulated by the provisions of the Military Border law in 1807. However, the interrelationships and organization of life and economy in a particular household were adjusted to the living circumstances of the given. Therefore, we have illustrated specific variations of the role of the mistress after taking over for the master of the zadruga, which was especially characteristic of the final stage of its existence, because most likely some family members persisted in maintaining the principles of zadruga rule, even after it had broken apart. The roles of the master and the mistress were more or less the same in both Bunjevci branches. The mistress often took over the management of the zadruga in the event that the master died or became seriously ill. In some of these zadrugas, she also shared this role with her eldest son, or with another one who was more capable of performing the duty. In a certain sense, that son acted as her assistant or deputy in matters of administration. 
The varied forms of female work distribution among the Danube area Bunjevci indicate that some types of labor distribution were similar to those of the Primorje/Lika area Bunjevci (which can be characterized as Dinaric type of female work distribution in extended families), while the periodic alternation of certain duties, a specific form known among some regional groups of the Danube area Bunjevci, is characteristic of the Pannonian area. Nevertheless, specific subtypes in the distribution of female labor (when the mistress has fixed duties while her daughters-in law help her with some tasks, which are often not entirely specified) could also be found in certain regions of western Hercegovina, southern Dalmatia and Montenegro (cf. ANDRIĆ 1972; ČERNELIĆ 2006:149-150). These features can be characterized as typical of the Bunjevci population in different regions, wherein they exist or existed in the past, despite various historical and socio-economic factors that influenced the formation of zadrugas over the course of history.

Differences concerning the way extended families were partitioned as well as the efforts to preserve them, or at least to retain certain features of zadruga life in the transitional period of its transformation to the nuclear family, characterize both branches of the Bunjevci subethnic group, regardless of how many variations there may be on a formal level. Initial research in 2011 among the third Bunjevci branch in Dalmatia indicated that the same tendencies survived in the region of Bukovica even longer, up to the last decade of the $20^{\text {th }}$ century. An interesting aspect is the preservation of the zadruga lifestyle in spite of the fact that members of the younger lived separately and earned a living outside the family, mostly by leaving for Germany for temporary work. Forms of cooperative existence adapted to a specific situation have remained in some families for longer or shorter periods of time as late as the 1990s (cf. BIRT - ČERNELIĆ 2014).

The specific transitional forms observed in the transformation of the zadruga to nuclear families may also partly be a result of the absence of proper legal procedure concerning extended families after the disintegration of the Military Border. The law after 1889 and the zadruga amendment after 1902 were not changed in the first four decades of the $20^{\text {th }}$ century (PAVLIČEVIĆ 2010:141). An interesting perspective was given by Dragutin Tončić, a lawyer who had been dealing with the issue of the extended family for years as a high government official in Croatia-Slavonia by 1918 and later as an advisor to the civil governor (ban) in the Kingdom of Serbs, Croats and Slovenians, when he wrote a book on this subject. Tončić was an advocate of preserving the zadruga as an institution for as long as economic and socio-political conditions allowed for it. Thus, he concluded the preface of his book in 1925 by stating that "the importance of the zadruga is still up-to-date" and that "no matter how much we speak of their survival, it is indisputable that the number of extended families, at least those consisting of a single family, has significantly increased lately, and the familial and household zadruga still continues to indicate our folk individuality and the life force of our peasants" (ToNČić 1925:5, acc. to PAVLIČEvić 2010:141-142)..$^{10}$ In accordance with the decision made by

\footnotetext{
${ }^{10}$ This article does not allow space for a further analysis of the legal aspects of extended families in the $20^{\text {th }}$ century, although it is of crucial importance in understanding this type of family life in general and the influence of various factors that brought about its disintegration. Detailed information on the legal regulation of zadrugas by the end of the $19^{\text {th }}$ and the beginning of the $20^{\text {th }}$ century was offered by Croatian historian Dragutin Pavličević in his second book published in 2010, which was dedicated to the issue of the zadruga.
} 
the AVNOJ (Anti-Fascist Council for the People's Liberation of Yugoslavia) in Jajce, in 1943, Yugoslav and Croatian communists repealed all pre-war laws, including the former civil laws which were in conflict the new political system of the newly formed country (cf. PAVLIČEvić 2010:241). In this way, the issue of the zadruga, along with the problem how to legally treat extended families as kinship communities, was not resolved due to the emergence of a legal vacuum. Tackling these problems came under court jurisdiction in 1947, but not without with some difficulties because in legal terms the singularities of the zadruga deviated from civil law norms. Lawyers finally adopted the attitude that the zadruga is, after all, "a property community sui generis with a pronounced familial element." In court practice, old acts which had been revoked were also used with regard to partition since regulating secretly partitioned extended families posed a particular problem. However, no special regulations or laws on the zadruga were passed (PAVLIČEVIĆ 2010:242). In the socio-political atmosphere of the socialist period, the extended family was also seen as an undesirable community because the aim of the new society was to abolish common property. It was thus proclaimed that zadrugas were inhibitors of socialist development, and so all legal means were made available in order to decimate the zadruga community (PAVLIČEvić 2010:250-251). Despite pressure from socialist authorities, particular extended families managed to survive in some other parts of Croatia as well, and not only in those inhabited by Bunjevci (cf. PAVLIČEvić 2010:252-258). The fact remains that within this "legal chaos", in practice, unwritten common law played an important part in the final legal resolution of the zadruga issue since former members of extended families tackled all the complex questions by means of internal agreement. The last surviving extended families in all three Bunjevci branches can serve as a good example of this. Nevertheless, we also need to stress the importance of ethnological research on the zadruga, conducted in the territories of Croatia and South-Eastern Europe. Therefore, proper partitioning - either by legal means or by agreement - is often not realized and the extended families in question mostly disappear as a result of a natural process of disintegration in the first half of the $20^{\text {th }}$ century, and in some cases even later, depending on individual circumstances as well as the prevalent socio-economic factors. As far as the subethnic group of Bunjevci is concerned, it is interesting to point out that these tendencies could be traced to certain regions of Hercegovina and the Dalmatian hinterland in the south-eastern Dinaric area, from which the Bunjevci originate. Common features of extended family life, in spite of their numerous variations, seem to be relevant traces which could result in a new understanding of the ethno-cultural formation of the Bunjevci ethnic group as well as a source of important facts about structure and life in the extended families of SouthEastern Europe. Some inherited features that characterized the extended family life of all three branches of Bunjevci survived, most likely as expression of common law and despite the strong influence of historical, socio-political, ecological and economic factors on Bunjevci family structure in the final stage of the existence of the zadruga. 


\section{REFERENCES CITED}

ANDRIĆ, Jasna

1972 Zadruga, novija istraživanja, njihova svrha i rezultati [Zadruga (the Extended Family), More Recent Research, its Aim and Results]. Etnološki pregled 10:57-76.

BIĆANIĆ, Rudolf

1936 Kako živi narod. Život u pasivnim krajevima [The Way the Folk Live. Life in Passive Regions]. Zagreb: Zavod za proučavanje seljačkog i narodnog gospodarstva "Gospodarska sloga".

1937 Agrarna kriza u Hrvatskoj 1973. do 1895 [Agrarian Crisis in Croatia from 1973 to 1895]. Zagreb: Vlastita naklada.

BIRT, Danijela Katić - Č́ERNelić, Milana

2014 Oblici zadružnog života u drugoj polovini 20. stoljeća u Kruševu (Bukovica) [Forms of Living within Extended Family Commune in the Second Half of the $20^{\text {th }}$ Century in Kruševo (Bukovica)]. In ČERnelić, Milana - GrbiĆ JAKOPOvić, Jadranka - RAJKović IvETA, Marijeta - RuBić, Tihana - DronjIĆ, Matija Gotal, Mihovil (eds) Bunjevci u vremenskom i prostornom kontekstu [The Bunjevci in the Context of Time and Space], 327-344. Zagreb: Sveučilište u Zagrebu, Filozofski fakultet Zagreb, Odsjek za etnologiju i kulturnu antropologiju, FF press - Zavod za kulturu vojvođanskih Hrvata, Subotica.

Bušič, Krešimir

2005 Bunjevci. 2. Povijest. Do doseljenja u Podunavlje [Bunjevci. 2. History]. In BAČić, Slaven (ed) Leksikon podunavskih Hrvata - Bunjevaca i Šokaca [Lexicon of the Dunabe Region for Croats-Bunjevacs and Sokacs], 48-53. Subotica: Hrvatsko akademsko društvo.

ČAPO ŽMEGAČ, Jasna

1996 Konstrukcija modela obitelji u Europi i povijest obitelji u Hrvatskoj [Construction of a Family Model in Europe and History of Family in Croatia]. Narodna umjetnost 33(2):179-196.

1998 Obitelji i kućanstva u Hrvatskoj [Families and Households in Croatia]. In Bratulić, Josip - HeKman, Jelena (eds) Hrvatska etnografija, Svagdan $i$ blagdan hrvatskog puka [Croatian Ethnography, Everyday and Holiday of the Croatian Folk], 252-263. Zagreb: Matica Hrvatska.

ČERNELIĆ, Milana

1999 Zadruga Rukavina-Jauci iz Smiljanskog Polja kod Gospića [The Extended Family Rukavina-Jauci from Smiljansko Polje near Gospić]. Senjski zbornik 26:297-312.

2005 Pristupi istraživanju bunjevačkih identiteta [Approaches to the Study of the Bunjevci identity]. Studia ethnologica Croatica 17:25-49.

2006 Bunjevačke studije [The Bunjevci Studies]. Zagreb: Sveučilište u Zagrebu, Filozofski fakultet, Odsjek za etnologiju i kulturnu antropologiju, FF-press. 
2007 Tragovi bunjevačkih elemenata u svadbenim običajima Dalmatinske zagore [Traces of Elements Pertaining to the Bunjevci Found in Wedding Customs in Dalmatian Hinterland]. In Kusin, Vesna (ed) Dalmatinska zagora - nepoznata zemlja [Dalmatian Hinterland - the Land Unknown], 583-588. Zagreb: Galerija Klovićevi Dvori.

2009 Običajno-pravni i imovinski aspekti života u obiteljskim zadrugama Like [Common-Law and Property-related Aspects of Living within Extended Family Communes in Lika]. Senjski zbornik 36:301-321.

2010 Velika familija Dulić na Đurđinu [The Large Dulić Family from Đurđin]. Godišnjak za znanstvena istraživanja Zavoda za kulturu vojvođanskih Hrvata 2:107-139.

2011. Velika kuća Ivana Opštinara na salašima Matarići kod Sombora - Usporedni osvrt na zadruge na salašima na Bezdanskom putu [Great House of Ivan Opštinar on Matarići granges near Sombor - Comparative Review on granges on Bezdan road]. Godišnjak za znanstvena istraživanja Zavoda za kulturu vojvođanskih Hrvata 3:187-204 ČERnELIĆ, Milana - RAJKović IvETA, Marijeta

2010 Ogled o primorskim Bunjevcima: povijesna perspektiva i identifikacijski procesi [A Review of the Littoral Bunjevci. Historical Perspective and the Processes of Identification]. Studia ethnologica Croatica 22:283-318.

Čulinović, Ferdo

1953 Državnopravna historija jugoslavenskih zemalja XIX i XX vijeka [History of State and Law of Yugoslav Countries in the $19^{\text {th }}$ and $20^{\text {th }}$ Century]. Zagreb: Školska knjiga.

Čulinović-Konstantinović, Vesna

1984 Običajno pravo, njegova primjena i proučavanje do polovine 20. Stoljeća [Common Law, its Practice and Studies by the Mid-20 ${ }^{\text {th }}$ Century]. Etnološka tribina 6-7:51-70.

1993 Bogišićevo proučavanje obitelji i njenih običajnopravnih institute [Studies of the Family and the Institution of Common Law by Bogišić]. Zbornik radova Pravnog fakulteta u Splitu 30(1):23-36.

ERDELJANOVIĆ, Jovan

1930 O poreklu Bunjevaca [The Origin of Bunjevacs]. Beograd: Sv. Sava.

Filipović, Milenko S. - Hammel, Eugine A.

1982 Among the People. Native Yugoslav Ethnography. Selected Writing of Milenko S. Filipović. Ann Arbor: Michigan Slavic Publications, Dept. of Slavic Language and Literatures.

FIRST-Dilić, Ruža

1974 O razmišljanjima Emila Sicarda [On Emil Sicard's Thoughts]. Sociologija sela 1:92-95.

GAvAZzi, Milovan

1959 Sudbina stare slavenske baštine kod južnih Slavena [Destiny of Old Slavic Heritage among the South Slavs]. Beograd: Biblioteka Etnološkog društva Jugoslavije.

1963 Novije činjenice za dokaz opstojanja zadruga u doba slavenske zajednice [More Recent Facts as Evidence of the Existence of the Extended Family Communes among the Slavs in Former Times]. Etnološki pregled 5:23-32. 
1978 Vrela $i$ sudbine narodnih tradicija kroz prostore, vremena i ljude [Origins and Destiny of Folk Traditions within Space, Time and People]. Zagreb: Sveučilišna naklada Liber.

GavazzI, Milovan (ed)

1960 Seljačke obiteljske zadruge I [Rural Extended Families I]. Zagreb: Publikacije Etnološkog zavoda Filozofskog fakulteta Sveučilišta u Zagrebu.

OваD, Željko (ed)

1992 Seljačke obiteljske zadruge II [Rural Extended Families II]. Zagreb: Otvoreno sveučilište.

GoODY, Jack

1972 The Evolution of the Family. In Laslett, Peter - WaLL, Richard (eds) Household and Family in the Past Time. Comparative Studies in the Size and Structure of the Domestic Group over the Last Three Centuries in England, France, Serbia, Japan and Colonial North America, with Further Materials from Western Europe, 103-124. Cambridge: Cambridge University Press.

GRBIĆ, Jadranka

2006 Hrvatska dijaspora $\mathrm{i}$ iseljeništvo [Croatian Diaspora and Emigrants]. In FoRJAN, Josip (ed) Narodne nošnje Hrvata u svijetu, tradicijsko odijevanje Hrvata izvan Republike Hrvatske [Folk Costumes of Croats in the World, Traditional Clothing of Croats outside the Republic of Croatia], 4-27. Zagreb: Posudionica i radionica narodnih nošnji.

HAJNAL, John

1965 European Marriage Patterns in Perspective. In Glass, D. V. - Eversley, D. E. C. (eds) Population in History. Essays in Historical Demography, 101143. London: Edward Arnold.

Hammel, Eugine A.

1972 Zadruga as Process. In LaSlett, Peter - Wall, Richard (eds) Household and Family in the Past Time. Comparative Studies in the Size and Structure of the Domestic Group over the Last Three Centuries in England, France, Serbia, Japan and Colonial North America, with Further Materials from Western Europe, 335-373. Cambridge: Cambridge University Press.

1975 Reflections on the Zadruga. Ethnologia Slavica 7:141-151.

HAREVEN, Tamara K.

1994 Recent Research on the History of the Family. In DraKe, Michael (ed) Time, Family and Community. Perspectives on Family and Community, 13-43. Oxford: Blackwell, The Open University.

HeĆIMOVIĆ-SESELJA, Mara

1960 Zadruga Ivčević-Hećimović, selo Ivčević Kosa - kotar Gospić [The IvčevićHećimović Extended Family, the Village of Ivčević Kosa - Gospić District]. In GavazzI, Milovan (ed) Seljačke obiteljske zadruge [Peasant Extended Families] I, 5-17. Zagreb: Publikacije Etnološkog zavoda Filozofskog fakulteta Sveučilišta u Zagrebu.

KASER, Karl

1997 Slobodan seljak i vojnik. Povojačeno društvo (1754-1881) [The Free Peasant and Soldier. Militarized Society (1754-1881)] II. Zagreb: Naprijed. 
2003 Popis Like i Krbave 1712. godine [Census of Lika and Krbava in 1712]. Zagreb: SKD Prosvjeta.

KAZER [Kaser], Karl

2002 Porodica i srodstvo na Balkanu. Analiza jedne kulture koja nestaje [Family and Kinship in the Balkans. An Analysis of a Disappearing Culture]. Beograd: Udruženje za društvenu istoriju.

LASLETT, Peter

1972 Introduction. The History of the Family. In LASLETT, Peter - WALL, Richard (eds) Household and Family in the Past Time. Comparative Studies in the Size and Structure of the Domestic Group over the Last Three Centuries in England, France, Serbia, Japan and Colonial North America, with Further Materials from Western Europe, 1-89. Cambridge: Cambridge University Press.

LASlett, Peter - Clarke, Marilyn

1972 Houseful and Household in an Eighteen-Century Balkan City. A Tabular Analysis of the Listing of the Serbian Sector of Belgrade in 1733-1734. In LASLETT, Peter - WALL, Richard (eds) Household and Family in the Past Time. Comparative Studies in the Size and Structure of the Domestic Group over the Last Three Centuries in England, France, Serbia, Japan and Colonial North America, with Further Materials from Western Europe, 375-400. Cambridge: Cambridge University Press.

LEČEK, Suzana

2003 Seljačka obitelj u sjeverozapadnoj Hrvatskoj 1918-1941 [The Peasant Family in North-West Croatia 1918-1941]. Zagreb, Slavonski Brod: Srednja Europa, Hrvatski Institut za povijest, Podružnica za povijest Slavonije, Srijema i

MirdiTA, Zef Baranje.

1995 Balkanski Vlasi u svijetlu podataka bizantskih autora [The Balkan Vlachs according to Byzantine Authors]. Povijesni prilozi 14:25-115.

PAVLIČEviĆ, Dragutin

1989 Hrvatske kućne zadruge I (do 1881.) [Croatian Extended Families Households I (until 1881)]. Zagreb: Sveučilišna naklada Liber.

1989a Seobe Vlaha Krmpoćana u XVII. stoljeću [Migration of Krmpote Vlachs in the $17^{\text {th }}$ Century]. In Vojne krajine u jugoslovenskim zemljama $u$ novom veku do Karlovačkog mira 1699 [Military Frontiers in Yugoslav Countries in the Modern Period until the Peace Treaty of Karlovac in 1699], 147-168. Beograd: Srpska akademija nauka i umetnosti.

2010 Hrvatske kućne/obiteljske zadruge II (nakon 1881.) [Croatian Extended Families Households II (after 1881)]. Zagreb: Golden marketing-Tehnička knjiga.

Petrić, Mario

1966 Prilog proučavanju porijekla Bunjevaca [Contribution to the Study of Origin of Bunjevacs]. Glasnik Zemaljskog muzeja u Sarajevu, n. s. 20-21:309-382.

RiHTMAN-Auguštin, Dunja

1984 Struktura tradicijskog mišljenja [Structure of Traditional Thought]. Zagreb: Školska knjiga, Stvarnost. 
2004 Ethnology, Myth and Politics. Anthropologizing Croatian Ethnology, ČAPO ŽMEGAČ, Jasna (ed). Burlington: Ashgate.

Rogić, Pavle

1966 Antroponimija u naseljima sjevernog Velebita [Anthroponymy in North Velebit Settlements]. In Hrvatski dijalektološki zbornik, Knj. 2: 325-355. Zagreb: Jugoslavenska akademija znanosti i umjetnosti.

RoKSANDIĆ, Drago

1988 Vojna Hrvatska - La Croatie Militaire [Military Croatia - La Croatie Militaire]. Zagreb: Školska knjiga.

ROTHENBERG, Gunther E

1960 The Austrian Military Border in Croatia, 1522-1747. Urbana, IL: University of Illinois Press.

1966 The Austrian Military Border in Croatia, 1740-1881. A Study of an Imperial Institution. Chicago: University of Chicago Press.

RuBIĆ, Tihana - BIRT Danijela

2009 Obiteljski život, odnosi i vrijednosti [Family Life, Relations and Values]. In ČERnelić, Milana - RAJKović, Marijeta - Rubić, Tihana (eds) Živjeti na Krivom Putu. Etnološka monografija o primorskim Bunjevcima, Svezak 2 [To Live on Krivi Put. Ethnological Monograph on the Littoral Bunjevci, Vol. 2], 31-56. Zagreb: Odsjek za etnologiju i kulturnu antropologiju, Gradski muzej Senj, FF-press.

Segalen, Martine

1997 Srodstveni odnosi u zapadnim (zapadnoeropskim) društvima. Povijesne i suvremene perspective [Kinship Relations in Western (West-European) Societies. Historical and Contemporary Perspectives], Etnološka tribina 20:29-47.

SiCARD, Emile

1974 Razmišljanja o postojanju i konceptu kućnih ekonomskih zajednica [Thoughts on the Existence and Concept of Household Economic Communes]. Sociologija sela $43: 28-53$.

\section{STEIN ERLICH, Vera}

1964 Jugoslavenska porodica u transformaciji [The Yugoslav Family Undergoing Transformation]. Zagreb: Liber.

ŠARIĆ, Marko

2008 Bunjevci u ranome novom vijeku: postanak i razvoj jedne predmoderne etnije [Bunjevci in the Early Modern Period. The Making and Development of a PreModern Ethnic]. In ČERnelić, Milana - RaJković, Marijeta - RuBić, Tihana (eds) Živjeti na Krivom Putu. Etnološko-povijesna monografija o primorskim Bunjevcima, Svezak 1 [To Live on Krivi Put. Ethnological and Historical Monograph on the Littoral Bunjevci, Vol. 1], 15-43. Zagreb: Odsjek za etnologiju i kulturnu antropologiju, Gradski muzej Senj, FF-press.

TODOROVA, Maria

1986 Myth-making in European Family History (The Zadruga revisited). European Politics and Societies 4(1):1-54. 
Milana Černelić is a full professor in the Department of Ethnology and Cultural Anthropology, Faculty of Humanities and Social Sciences, University of Zagreb, leader of the projects Identity and Ethnogenesis of the Littoral Bunjevci (2002-2006) and Identity and Ethnocultural Shaping of the Bunjevci (2008-2013). She is the author of three books, editor-in-chief of one monograph, and co-editor of several monographs and collections of papers. Her main research interests are customs and rituals, family, ethnicity and construction of identity of Croatian minorities and subethnic groups (primarily the subethnic group of Bunjevci in Croatia, Hungary and Serbia), ethnological methodology, and the role of the ethnologist in the development of rural tourism. E-mail address: mcerneli@ffzg.hr

Tihana Rubić is assistant professor in the Department of Ethnology and Cultural Anthropology, Faculty of Humanities and Social Sciences, University of Zagreb. She received her PhD in 2012 in ethnology and cultural anthropology. She was a research assistant for the project Identity and Ethnocultural Shaping of the Bunjevci (2008-2013). She is a co-editor of several monographs and collections of papers and the editor-in-chief of the journal Studia etnologica Croatica. Her main research interests are family and kinship, informal economy and urban gardening. E-mail address: trubic@ffzg.hr 